\title{
Alien parasitic copepods in mussels and oysters of the Wadden Sea
}

\author{
Nikolaus O. Elsner $\cdot$ Sabine Jacobsen $\cdot$ \\ David W. Thieltges $\cdot$ Karsten Reise
}

Received: 10 May 2010/Revised: 21 July 2010/Accepted: 2 September 2010/Published online: 18 September 2010

(C) Springer-Verlag and AWI 2010

\begin{abstract}
Molluscan intestinal parasites of the genus Mytilicola, specifically $M$. intestinalis, were initially introduced into bivalves in the North Sea in the 1930s. It was presumably introduced from the Mediterranean with ship-fouling mussels, then attained epidemic proportions in Mytilus edulis in the 1950s and is now widely established in the North Sea region. Mytilicola orientalis was cointroduced with Pacific oysters to France in the 1970s and in the southern North Sea in the early 1990s. Its main host Crassostrea gigas has massively invaded the Wadden Sea with a concomitant decline in mussels. To explore whether introduced mytilicolid parasites could play a role in the shifting dominance from native mussels to invasive oysters, we analysed 390 mussels and 174 oysters collected around the island of Sylt in the northern Wadden Sea. We show that $M$. intestinalis has a prevalence $>90 \%$ and a mean intensity of 4 adult copepods in individual mussels with $>50 \mathrm{~mm}$ shell length at all sheltered sites. By contrast, none were found in the oysters. However, at one site, we found M. orientalis in C. gigas with a prevalence of $10 \%$ and an intensity of 2 per host individual (August 2008).
\end{abstract}

N. O. Elsner $(\bowtie)$

Zoological Institute and Zoological Museum,

University Hamburg,

Martin-Luther-King-Platz 3,

20146 Hamburg, Germany

e-mail: nikolaus.elsner@uni-hamburg.de

S. Jacobsen · K. Reise

Alfred Wegener Institute for Polar and Marine Research,

Wadden Sea Station Sylt, Hafenstraße 43,

25992 List/Sylt, Germany

D. W. Thieltges

Royal Netherlands Institute for Sea Research (NIOZ),

P.O. Box 59, Den Burg, 1790 AB Texel, The Netherlands
This constitutes the most northern record in Europe for this Pacific parasite until now. Alignments of partial sequences of the mitochondrial cytochrome oxidase I (COI) gene and the nuclear internal transcribed spacers (ITS) and $18 \mathrm{~S}$ rDNA sequences each show a distinct difference between the two species, which confirms our morphological identification. We suggest that the high parasite load in mussels compared to oysters may benefit the continued expansion of $C$. gigas in the Wadden Sea.

Keywords Introduced species - Mussels - Mytilicola · Oysters $\cdot$ Parasites $\cdot$ Wadden Sea

\section{Introduction}

Invasions of alien species have become a major process of change in marine coastal ecosystems (Ruiz et al. 1997; Reise et al. 2006; Rilov and Crooks 2009). Parasites may have two different effects on this global process. On the one hand, introduced species often escape from their native parasites during transport and when founder populations are rather small (Torchin and Lafferty 2009). In addition, parasites with complex life cycles seldom encounter all necessary hosts in a recipient ecosystem and thus are rarely co-introduced (Torchin et al. 2003), and native parasites tend to infest alien hosts only at low numbers (Krakau et al. 2006). This parasite release is assumed to generally facilitate invasive hosts.

On the other hand, with transfers of organisms for aquaculture and to some extent also with ships or the aquaria trade, diseases and parasites have been introduced with occasionally disastrous effects when they infest naïve (previously unexposed) host species in a recipient coastal region (Cook et al. 2008; Minchin et al. 2009; Pillay 2004). 
Particularly, oyster stocks have been strongly affected by introduced disease agents (Andrews 1980; Wolff and Reise 2002). Many of these parasites mature and reproduce on or in a single host, and spores or larvae disperse to the next host individual (direct life cycle). This makes their invasion more likely compared to parasites with complex life cycles which depend on the presence of all hosts to become established. Parasitic copepods of the genus Mytilicola exemplify the type of invasive parasites with direct life cycles. They inhabit the guts of molluscs and disperse via larval stages to infect other host individuals (Lauckner 1983; Gotto 2004). In European seas, M. intestinalis has been described from the mussel Mytilus galloprovincialis in the Adriatic Sea by Steuer (1902). On the Atlantic coast, it appeared in M. edulis in England and in the German Bight in the 1930s (Caspers 1939; Korringa 1968) and is believed to have been imported with mussels fouling ship hulls (Korringa 1968).

However, for British waters, Eno et al. (1997) have not included $M$. intestinalis as an introduced species, based on a pers. comm. by M. Gee "that its biology suggests that it is a boreal species" (p. 12). This remark seems to be derived from results in Gee and Davey (1986), showing that development can be completed at temperatures below $18^{\circ} \mathrm{C}$ albeit at slow rates. We follow Korringa (1968) who assumes it as very unlikely that this highly conspicuous parasite has been overlooked in North Sea mussels prior to the 1930s, and thus regard M. intestinalis as an introduced rather than being a cryptogenic species.

From 1949 to 1951, an epidemic was observed at the North Sea coast, and M. intestinalis was blamed for massive mortality in M. edulis with a severe impact on the mussel fishery (Korringa 1968). Although this parasite evidently can harm its host (e.g. Meyer and Mann 1950; Williams 1969; Mann 1979; Theisen 1987), doubts have been raised as to whether $M$. intestinalis has been the causal agent for the observed mortality in the mussel epidemic or as to whether it merely had spread coincidentally at that time (Dethlefsen 1975; Lauckner 1983).

A second Mytilicola species, M. orientalis, has been described by Mori (1935) from the Pacific oyster Crassostrea gigas and mussels in the Inland Sea of Japan, and this species was first introduced with its host $C$. gigas to the Pacific coast of North America in the 1930s and to France in the 1970s (Katkansky et al. 1967; His 1977; His et al. 1978; Lauckner 1983; Grizel 1985). On the European Atlantic coast, it has spread further to the Netherlands and Ireland (Stock 1993; Holmes and Minchin 1995) and has also been introduced with $C$. gigas into the Mediterranean Sea (Clantzig 1989). Although it was initially feared that $M$. orientalis could initiate an epidemic similar to the one assumed with $M$. intestinalis in 1949-1951, this has not yet been observed, and harm to the host $C$. gigas seems to be small (Deslous-Paoli and Héral 1988; De Grave et al. 1995; Steele and Mulcahy 2001).

In the northern Wadden Sea, the typical hosts for these two parasites co-occur. While the mussels $M$. edulis are native, the oysters $C$. gigas have recently been introduced. Regular imports of young Pacific oyster $C$. gigas for sea ranching at Sylt island have occurred since 1986, and the oysters subsequently invaded mussel beds in that area (Reise 1998; Diederich et al. 2005). The question arose as to whether $C$. gigas could displace the native mussels (Diederich 2005, 2006; Nehls et al. 2006). Direct competition between mussels and oysters for space and food has been suggested (Troost 2009), but it also seems likely that indirect competition mediated by differential parasite loads among the two host species (apparent competition) could be another contributing factor (Krakau et al. 2006).

The aim of our study was to investigate mussels and oysters for the presence of the two parasitic copepod species and to quantify the respective infection levels in their hosts. To test the selectivity of the infestation, we experimentally investigated the host specificity of $M$. intestinalis in mussels and oysters. Due to ambiguous features of species identification mentioned in the literature (Stock 1993, Gotto 2004), we sequenced parts of the nuclear rDNA and one mitochondrial gene to genetically verify species determination based initially on morphological features only.

\section{Materials and methods}

\section{Sampling area}

The 390 individuals of Mytilus edulis and 174 of Crassostrea gigas examined in this study were sampled at six sites around the island of Sylt in 2007 and 2008 (Fig. 1, Tables 1 and 2). The intertidal sampling sites in the north and in the south are disconnected by a dam from the island to the mainland since 1927. Sampling site 3 at the exposed beach refers to mussels attached to groins. All other mussels and the oysters collected were living on sediment in the low tidal zone and at one site in the shallow subtidal zone. The subtidal mussels collected in August 2007 were dredged at a depth of 1-2 $\mathrm{m}$, while the ones collected in May 2008 were collected by hand at a depth of about $0.5 \mathrm{~m}$ during extreme low tide. Regarding the two sites sampled for both mussels and oysters, the oyster bank was approximately $500 \mathrm{~m}$ from the mussel bank at site 2, whereas mussels and oysters co-occurred in a mixed assemblage at site 6 . For every host individual, the infestation of Mytilicola spp. was recorded to determine the mean prevalence ( $\%$ of host individuals infected) and the mean intensity (mean number of parasite individuals per 
Fig. 1 Sampling sites of mussels (squares) and oysters (asterisks) around the North Sea island of Sylt. 1 Ellenbogen, 2 List, 3 Kampen, 4 Leghörn, 5 Munkmarsch, 6 Puan Klent. Grey shaded areas indicate the intertidal zone

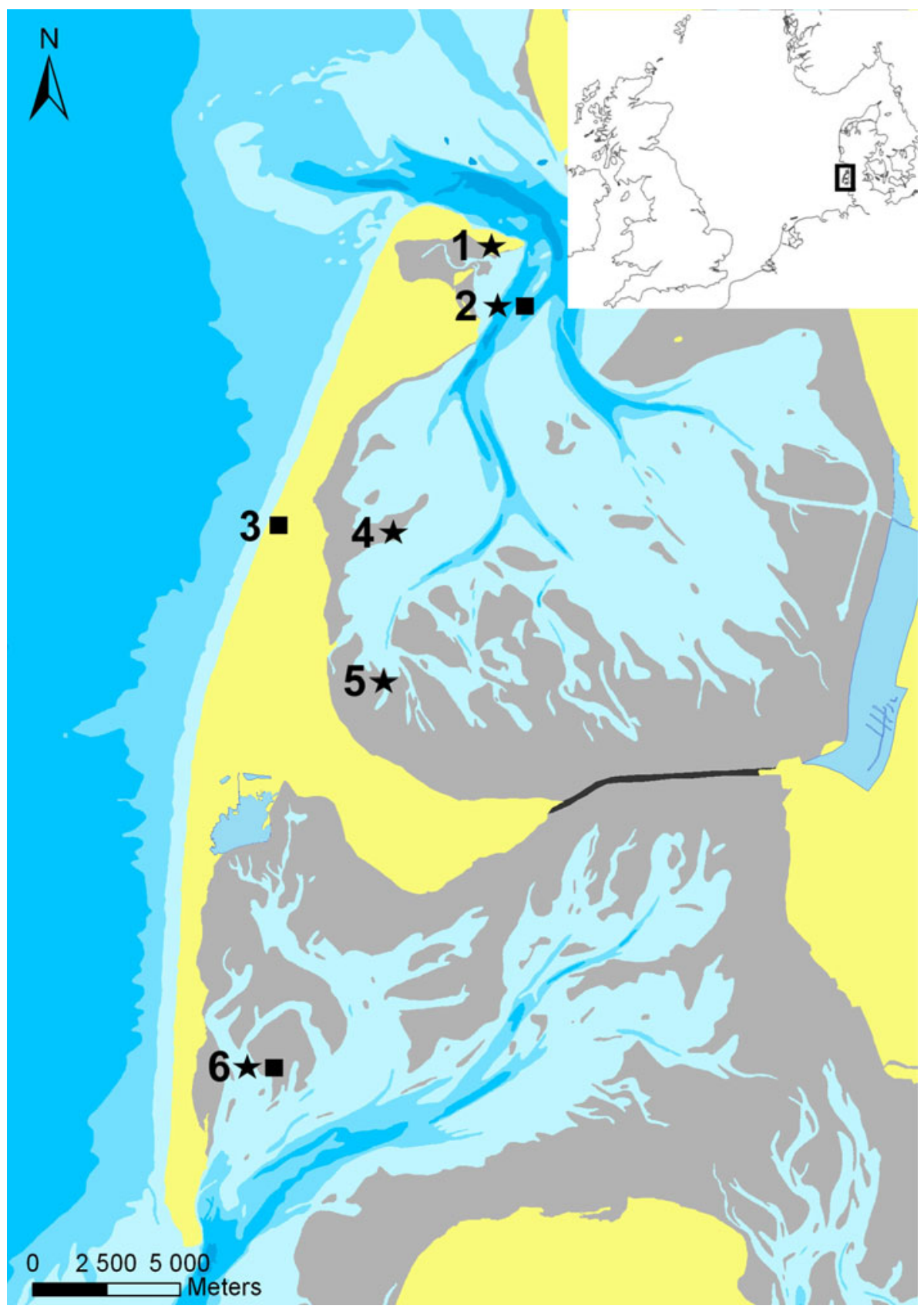

Table 1 Crassostrea gigas investigated for intestinal copepods with locality (see Fig. 1), date, number, shell length (mean \pm standard deviation) prevalence (\% of host individuals infected) and intensity (mean \pm standard deviation)

\begin{tabular}{lllccc}
\hline Site & Date & Oysters $\mathrm{n}$ & Shell length $(\mathrm{mm})$ & Prevalence $(\%)$ & Intensity \pm SD \\
\hline 1 & May 2008 & 30 & $95.3 \pm 28.4$ & 0.0 & 0.0 \\
2 & August 2007 & 19 & $80.8 \pm 26.5$ & 0.0 & 0.0 \\
2 & August 2008 & 55 & $91.0 \pm 21.5$ & 0.0 & 0.0 \\
4 & May 2008 & 10 & $128.1 \pm 20.0$ & 0.0 & 0.0 \\
5 & May 2008 & 30 & $107.0 \pm 24.7$ & 0.0 & 0.0 \\
6 & August 2008 & 30 & $106.2 \pm 22.1$ & 10.0 & $1.7 \pm 0.6$ \\
\hline
\end{tabular}

Only Mytilicola orientalis was found in C. gigas 
Table 2 Mytilus edulis investigated for intestinal copepods with locality (see Fig. 1), date, number, shell length (mean \pm standard deviation) prevalence ( $\%$ of host individuals infected) and intensity (mean \pm standard deviation)

\begin{tabular}{lllllll}
\hline Site & Date & Mussels n & Shell length $(\mathrm{mm})$ & Category & Prevalence $(\%)$ & Intensity \pm SD \\
\hline 2 & August 2007 & 30 & $24.1 \pm 3.9$ & Small & 33.33 & $1.60 \pm 0.97$ \\
2 & August 2007 & 30 & $38.1 \pm 5.1$ & Medium & 63.33 & $4.05 \pm 2.98$ \\
2 & August 2007 & 30 & $57.6 \pm 6.4$ & Large & 90.00 & $4.48 \pm 3.32$ \\
$2 *$ & August 2007 & 30 & $72.7 \pm 6.4$ & Large & 93.33 & $8.07 \pm 4.75$ \\
$2 *$ & May 2008 & 30 & $70.3 \pm 8.1$ & Large & 86.67 & $3.81 \pm 2.95$ \\
$2 *$ & August 2008 & 120 & $68.0 \pm 8.1$ & Large & 93.30 & $5.28 \pm 3.53$ \\
3 & August 2007 & 30 & $35.7 \pm 3.1$ & Medium & 3.33 & $1.0 \pm 0.18$ \\
3 & May 2008 & 30 & $32.7 \pm 1.6$ & Medium & 0.0 & $0.0 \pm 0.0$ \\
6 & August 2007 & 30 & $60.1 \pm 4.2$ & Large & 93.33 & $4.18 \pm 3.25$ \\
6 & August 2008 & 30 & $66.5 \pm 3.7$ & Large & 96.67 & $3.72 \pm 2.76$ \\
\hline
\end{tabular}

Only Mytilicola intestinalis was found in M. edulis *subtidal, all others intertidal

infected host individuals) of the two copepods in each host population.

Mussels were divided into three shell length categories: small $(<30 \mathrm{~mm})$, medium $(30-50 \mathrm{~mm})$ and large (>50 mm; cp. Meyer and Mann 1950). These categories have previously been shown to be positively correlated with prevalence and intensity of $M$. intestinalis (e.g. Dethlefsen 1975). Due to the fact that the last recruitment event in C. gigas had occurred in summer 2006, small oysters were not available and random samples were taken.

After mussels and oysters were opened, the visceral mass was taken out and squeezed between two glass plates. Only adult stages of Mytilicola spp. were counted. These are readily detected due to their size and intensive red colour.

To detect statistically significant differences in infection levels, prevalence and intensity data were compared using chi-square test and analysis of variance (ANOVA), respectively.

\section{Infection experiment}

In order to test the host specificity of $M$. intestinalis with regard to $M$. edulis and C. gigas, a pilot study was conducted from the beginning of September to the beginning of November 2008. We infected previously uninfected individuals (medium-size mussels from site 3 and oysters from site 2 , recipient mussels and oysters) by keeping them together in treatments with highly infected large blue mussels (from site 2, donor mussels) for 2 months. Recipient mussels were marked and could readily be distinguished by their size. The average rate of infection of recipient mussels and oysters and donor mussels was determined before the experiment commenced with samples of $n=30$ for each host species (see Tables 1 and 2, samples from 2008). Epibionts of mussels were removed prior to the experiment.

Twelve aquaria (20 1) were used, each containing 10 donor mussels. Recipient mussels and oysters were exposed to infected mussels separately to prevent mutual interference. Therefore, six treatments were used for the infection of mussels and 6 for the infection of oysters. Of the recipient mussels and oysters, 6 individuals were added to each treatment. The bivalves were kept in oxygenated sea water filtered with a gravel filter. Every day, 31 of each tank were renewed. Once every week, the whole tank was filled with fresh filtrated sea water. Previously uninfected mussels and oysters $(n=20$ each) were kept as a control in unfiltered seawater. Water temperature remained at $15^{\circ} \mathrm{C}$ during the entire experiment. After 2 months, all individuals were simultaneously taken out of the water and stored at $4^{\circ} \mathrm{C}$ until dissection within 2 weeks. Cooled storage is assumed to have no effect on the intensity of the infestation (Dethlefsen 1972).

Genetic species differentiation

For the genetic differentiation of the species, the DNA of 5 specimens of Mytilicola intestinalis and 2 of M. orientalis was extracted using the Qiagen DNeasy Blood and Tissue Kit. From this extracted DNA, the sequences of the $18 \mathrm{~S}$ rDNA, the internal transcribed spacers (ITS) of the rDNA and sequences of the $5^{\prime}$ part of the mitochondrial cytochrome c oxidase I (COI) gene were determined after amplification using polymerase chain reaction (PCR). Due to its length, the $18 \mathrm{~S}$ sequence was divided into 3 overlapping parts which were separately amplified using three sets of forward and reverse primers. All primers used are specified in Table 3. The annealing temperature was set to 
Table 3 Name and sequence of primers used for PCR amplification and sequencing
Fig. 2 Prevalence and intensity of Mytilicola intestinalis in its host Mytilus edulis and of $M$. orientalis in its host Crassostrea gigas at sampling site 6 in August 2008 (see Fig. 1, Tables 1 and 2). $n=30$ for each asterisk statistically significant difference

\begin{tabular}{lll}
\hline Primer name & Sequence $5^{\prime} \rightarrow 3^{\prime}$ & Reference \\
\hline COI f & GGTCAACAAATCATAAAGATATTGG & Folmer et al. (1994) \\
COI r & TAAACTTCAGGGTGACCAAAAAATCA & Folmer et al. (1994) \\
ITS1 f & TCCGTAGGTGAACCTGCGG & White et al. (1990) \\
ITS4 r & TCCTCCGCTTATTGATATGC & White et al. (1990) \\
$18 \mathrm{~S} \mathrm{f}$ & TACCTGGTTGATCCTGCCAG & Huys et al. (2006) \\
$18 \mathrm{~S} 554 \mathrm{f}$ & AAGTCTGGTGCCAGCAGCCGC & Huys et al. (2006) \\
$18 \mathrm{~S} 1150 \mathrm{f}(\mathrm{p} 2)$ & ATTGACGGAAGGGCACCACCAG & Huys et al. (2006) \\
$18 \mathrm{~S} 614 \mathrm{r}$ & TCCACCTACGAGCTTTTTAACC & Huys et al. (2006) \\
$18 \mathrm{~S} 1282 \mathrm{r}$ & TCACTCCACCAACTAAGAACGGC & Huys et al. (2006) \\
$18 \mathrm{~S} \mathrm{r}$ & TAATGATCCTTCCGCAGGTTCAC & Huys et al. (2006) \\
\hline
\end{tabular}

Intensity

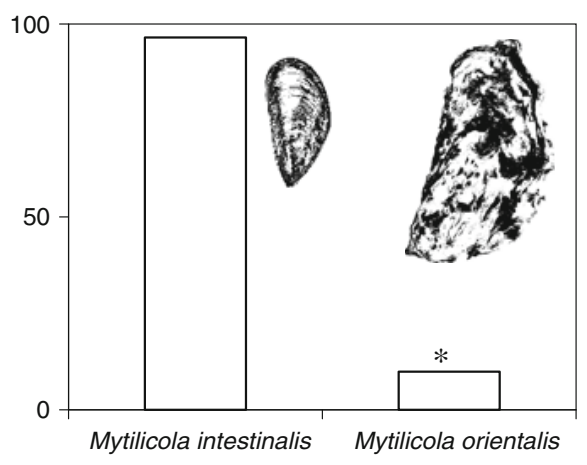

\section{Intensity}

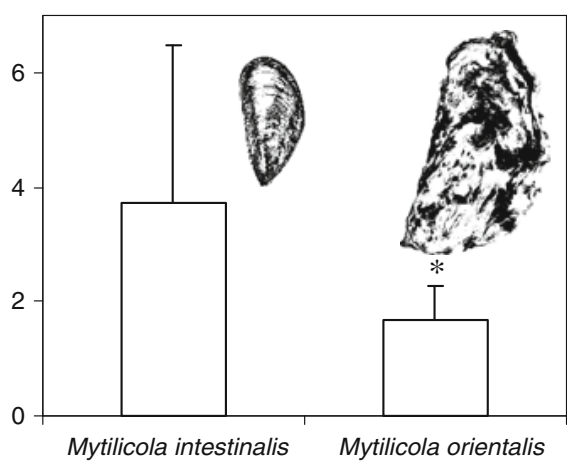

$57^{\circ} \mathrm{C}$ for the $18 \mathrm{~S}$ primers and to $50^{\circ} \mathrm{C}$ for the COI and ITS primers. The PCR products were purified using the Qiagen QIAquick PCR Purification Kit and sent to Eurofins MWG Operon for sequencing. The three parts of the $18 \mathrm{~S}$ sequence were manually rejoined to one sequence of 1,728 base pairs based on the overlapping regions. The sequences are available in GenBank under the accession numbers HM775187-HM775206.

The 18S rDNA, the COI and the ITS sequences of M. intestinalis and M. orientalis were inserted into an alignment using ClustalX (Higgins and Sharp 1988). Based on this alignment, the percentage of differing bases was calculated. All three genomic regions were determined in both $M$. orientalis individuals analysed. Regarding $M$. intestinalis, COI and ITS sequences were obtained from all five individuals while for the $18 \mathrm{~S}$ sequencing, only two individuals were used.

\section{Results}

Infection levels in mussels and oysters

Almost all mussel populations were infected with M. intestinalis, and all mussels were free of M. orientalis
(Tables 1 and 2). Prevalence and intensity were generally high in large mussels ( $>90 \%$ and approx. 4 parasites/host), and only medium mussels from the exposed shore of the island (site 3 ) had very low infection values (Table 1). In contrast, oysters were free of $M$. intestinalis, and $M$. orientalis was found only at a single sampling site (Fig. 1, site $\left.6 ; 54.7917^{\circ} \mathrm{N}, 8.3056^{\circ} \mathrm{E}\right)$. At this site, infection levels of $M$. intestinalis in mussels were significantly higher than of $M$. orientalis in oysters (Fig. 2; prevalence: $\chi^{2}=45.3$; intensity: $\left.F_{59}=44.3, P<0.001\right)$.

\section{Experimental infections}

This pilot experiment yielded no infection of oysters but a noticeable infection of previously uninfected mussels (recipient mussels). Approximately, half of the recipient mussels in each aquarium were infected (mean prevalence $45.6 \pm 7.2 \%, n=35$ ) with one or two M. intestinalis in each mussel (mean intensity $1.3 \pm 0.3$ ). After the experiment, the donor mussels used for the infection had a prevalence of $93.3 \%$ and an intensity of $5.3 \pm 3.5$. (The control mussels, previously uninfected but kept in unfiltered seawater, unexpectedly showed similar infection rates (prevalence $30.0 \%$ and intensity $1.7 \pm 0.9$ ). Again, oysters remained uninfected.) 
Table 4 Inter- and intraspecific sequence differences determined in M. intestinalis and M. orientalis

\begin{tabular}{lrlll}
\hline Sequence & $\begin{array}{l}\text { Base } \\
\text { pairs }\end{array}$ & $\begin{array}{l}\text { Interspecific } \\
(\%, \min / \max )\end{array}$ & $\begin{array}{l}\text { M. intestinalis } \\
\text { intraspecific }(\%)\end{array}$ & $\begin{array}{l}\text { M. orientalis } \\
\text { intraspecific }(\%)\end{array}$ \\
\hline $18 S$ & 1,744 & $1.20 / 1.26$ & 0.0 & 0.06 \\
COI & 628 & $16.08 / 16.40$ & 0.0 & 0.64 \\
ITS & 515 & 14.17 & 0.0 & 0.19 \\
\hline
\end{tabular}

For interspecific values, minimal (min) and maximal (max) values are shown

Genetic species differentiation

A comparison of the $M$. intestinalis and $M$. orientalis sequences obtained showed notable differences regarding intra- and interspecific variation. Intraspecifically, no sequence variation existed between the analysed individuals of M. intestinalis (based on five individuals for the COI and ITS sequences and two individuals for the $18 \mathrm{~S}$ region). For the two M. orientalis individuals analysed, intraspecific variations were found in all three sequences, although they are well under $1 \%$ (Table 4).

The interspecific differences are much higher. Regarding the conserved $18 \mathrm{~S}$ sequence, they exceed $1 \%$. For COI and ITS, both sequence markers with higher mutation rates, differences above $10 \%$ were determined.

During our investigations, we noticed that morphological identification features mentioned by Stock (1993) and Gotto (2004) are problematic. The caudal rami are said to be strongly divergent in M. intestinalis and almost parallel in $M$. orientalis. According to our observations, this feature is not reliable because Mytilicola can actively pull on the caudal rami causing them to lie parallel or to spread them out until they lie at a $180^{\circ}$ angle to each other. We found the dorsal appendages to be the most suitable feature for identification: they are short and rounded in M. intestinalis and distinctly pointed and elongated in M. orientalis (Fig. 3).

\section{Discussion}

In the northern Wadden Sea, we found a heavy infestation of native mussels Mytilus edulis by the intestinal mytilicolid copepod Mytilicola intestinalis, indicating that this introduced parasite has become well established since the first record in 1970 (Dethlefsen 1972), while still absent in 1950 and 1965 (Meyer and Mann 1950; Theisen 1966). Prevalence and intensity in 2003-2004 (Thieltges et al. 2006, 2008) and in 2007-2008 (this study) have been at a similarly high level. In the invasive Pacific oyster Crassostrea gigas, we found no M. intestinalis. However, at a single site in the south of the island of Sylt, far away from the local oyster culture lot in the north of the island, we found for the first time oysters infected with M. orientalis. The nearest previously reported occurrence is the Rhine Delta in the Netherlands (Stock 1993), approximately $570 \mathrm{~km}$ along the North Sea shore in south-western direction. We speculate that this parasite may have just arrived at this northern most location for this Pacific species in Europe, although this site has not been screened previously. Thus, the sweeping invasion of $C$. gigas in the northern Wadden Sea presumably took place in the absence of this parasite burden.

The presence of both parasitic copepods was confirmed by the molecular analyses. Avise (2000) suggests $<1 \%$ for intraspecific and $>1 \%$ for interspecific COI variation. We found differences of $>1 \%$ even in the conserved $18 \mathrm{~S}$ sequence while COI sequences differed between $M$. intestinalis and $M$. orientalis by around $16 \%$. Thus, even when the limit of $1 \%$ for species differentiation based on COI variation may be low, our results reveal a clear genetic distinction between both species and point to a not very close phylogenetic relationship. This is supported by a comparison with a GenBank entry of the $18 \mathrm{~S}$ sequence of a third species of the Mytilicolidae, Trochicola entericus (Acc-No. AY627006). Differences between M. intestinalis
Fig. 3 Mytilicola intestinalis $(\mathbf{a}, \mathbf{b})$ and $M$. orientalis $(\mathbf{c}, \mathbf{d})$ in dorsal $(\mathbf{a}, \mathbf{c})$ and ventral $(\mathbf{b}$, d) view. Female with egg sacks (one missing in $M$. orientalis), and dwarf male in each figure. Loss of the intense red colour due to ethanol fixation. Note the dorsal protuberances (arrowheads) as a distinct differential character
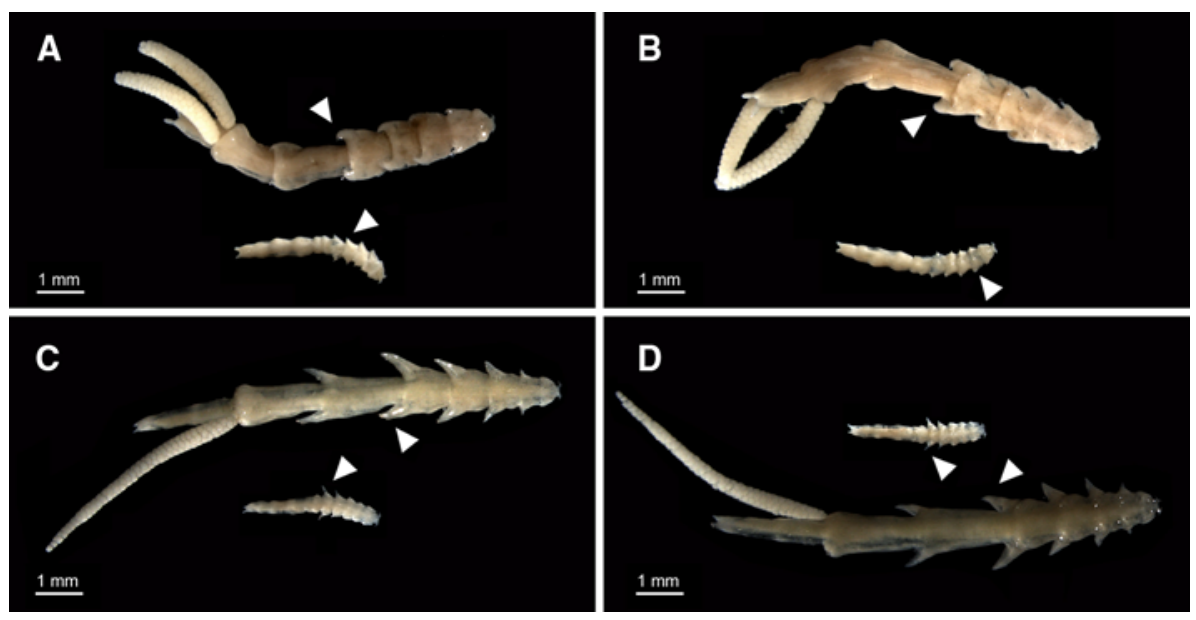
and $T$. entericus $(1.32 \%)$ were higher than between M. intestinalis and M. orientalis (max. $1.26 \%$ ).

Lauckner (1983) reviewed the host spectra of $M$. intestinalis and $M$. orientalis, listing a number of bivalve species and even some gastropods. Mytilids may even occasionally harbour both species concurrently in southern France (His 1977). However, M. intestinalis has not been recorded from Pacific oysters, except in a study by AguirreMacedo and Kennedy (1999) who refer to this species occurring throughout the year in $C$. gigas collected at the Exe estuary in southern England. This is in contrast to our observations since we did not find $M$. intestinalis in the 174 oysters screened for parasites, although all oysters were collected at sites where $M$. intestinalis occurred abundantly in mussels, often found in aggregates with the oysters. By referring to the above mentioned problem in species identification, we suggest that the only myticolid copepod in the intestine of $C$. gigas is M. orientalis.

Our experimental infections support our field observations that oysters are unsuitable as a host for $M$. intestinalis, as we yielded a high prevalence in mussels whereas the oysters remained free of this parasite. (The unexpected infection of mussels kept separate from mussels with $M$. intestinalis was most likely due to the fact that the water supply system for the flow-through tanks of the experiment has its incurrent syphon not far away from a subtidal mussel bed which is heavily infected by M. intestinalis.) Nevertheless, this pilot experiment may indicate that Pacific oysters are not infected by $M$. intestinalis. Unfortunately, we could not get enough $C$. gigas with $M$. orientalis to conduct the reverse infection experiment.

That $M$. orientalis was encountered only at a single site in $C$. gigas near the southern tip of the island was unexpected because the only oyster farm in the region is near the northern tip of the island, and this company regularly imports young oysters from Irish sources where $M$. orientalis has already been reported to infest $C$. gigas (Holmes and Minchin 1995; Steele and Mulcahy 2001). The sites in the north and south of Sylt are separated by a dam connecting the island with the mainland (see Fig. 1). Natural dispersal has to take a route all along the exposed shore of the island where $C$. gigas does not occur, and this amounts to a distance of at least $50 \mathrm{~km}$, mostly against the residual currents. Thus, maybe it is more likely that $M$. orientalis has arrived in the northern Wadden Sea by spreading from the south within a C. gigas population which originates from cultures in the delta area of the Netherlands. Site 6 is located in an area with intensive mussel cultures with seed mussels taken from various sources. Pacific oysters could have been transferred together with mussels.

According to the literature, $M$. intestinalis has little or no effects on mussel growth and reproduction performance when intensity is low, but negative effects are evident at the intensities of 3 and higher (Meyer and Mann 1950; Gee and Davey 1986; Theisen 1987). Likewise, M. orientalis does not harm its host $C$. gigas at low intensities (Steele and Mulcahy 2001), but has a negative effect at the intensities of 3 and more (Odlaug 1946; Katkansky et al. 1967; Deslous-Paoli 1981). At the sampling site where both parasites occur, $M$. intestinalis has an intensity of about 4 in $M$. edulis, while that of $M$. orientalis was only about 2 in $C$. gigas. Thus, mussels are likely to suffer from its intestinal parasite, while the oysters are probably not. This suggests that the invasive oysters may have a competitive advantage over the native mussels in the northern Wadden Sea as a result of their unequal parasite burdens. However, differential loads with parasitic copepods are not the only competitive advantage of oysters. They may also be less susceptible to predators (crabs, shrimp, starfish), presumably due to their firm attachment, flat shape when small and with a sturdy shell when larger (own observation). And they also show low burdens of trematode parasites which regularly infect the native mussels (Krakau et al. 2006). The differential infestation of native mussels and invasive oysters with mytilicolid parasites may thus have contributed to the success of the oyster invasion. However, this difference may be attributed to the fact that $M$. orientalis has arrived very recently, six decades after the introduction of $M$. intestinalis in the North Sea region and nearly four decades after $M$. intestinalis was first found where we now have encountered $M$. orientalis. Future studies will have to show whether $M$. orientalis can attain the same level of infestation in $C$. gigas as $M$. intestinalis does in M. edulis.

Acknowledgments We thank our colleagues at the Wadden Sea Station Sylt of the Alfred Wegener Institute for Polar and Marine Research, especially Christian Buschbaum and Manulea Krakau, for inspiring discussions. Dagmar Lackschewitz is thanked for providing us with overlooked references. Elisabeth Herre and Reimer Magens are thanked for technical support. Tobias Dolch kindly provided the map of Sylt.

\section{References}

Aguirre-Macedo ML, Kennedy CR (1999) Diversity of metazoan parasites of the introduced oyster species Crassostrea gigas in the Exe estuary. J Mar Biol Assoc UK 79:57-63

Andrews J (1980) A review of introductions of exotic oysters and biological planning for new importations. Mar Fish Rev 42:1-11

Avise JC (2000) Phylogeography: the history and formation of species. Harvard University Press, Cambridge

Caspers H (1939) Über Vorkommen und Metamorphose von Mytilicola intestinalis STEUER (Copepoda paras.) in der südlichen Nordsee. Zool Anz 126:161-171

Clantzig S (1989) Invertebrates d'introduction récente dans les lagunes méditerranéennes du Languedoc-Roussillon (France). Bull Soc Zool Fr 114:151-152 
Cook EJ, Ashton G, Campbell M, Coutts A, Gollasch S, Hewitt C, Liu H, Minchin D, Ruiz G, Shucksmith R (2008) Non-native aquaculture species releases: implications for aquatic ecosystems. In: Holmer $\mathrm{M}$ et al (eds) Aquaculture in the ecosystem. Springer science and business media, New York, pp 155-184

De Grave S, Xie Q, Casey D (1995) The intensity of infection by the intestinal copepod, Mytilicola orientalis, does not affect the condition of Pacific oysters (Crassostrea gigas). Bull Eur Assoc Fish Pathol 154:129-131

Deslous-Paoli JM (1981) Mytilicola orientalis Mori, Crassostrea gigas Thunberg's parasite in the basin of Marennes-Oleron: impact on the condition and biochemical composition of oysters during rearing. ICES CM 1981/K:29

Deslous-Paoli JM, Héral M (1988) Biochemical composition and energy value of Crassostrea gigas (Thunberg) cultured in the bay of Marennes-Oléron Aquat. Living Resour 1:239-249

Dethlefsen V (1972) Zur Parasitologie der Miesmuschel (Mytilus edulis L., 1758). Ber Deut Wiss Komm Meeresforsch 22: 344-371

Dethlefsen V (1975) The influence of Mytilicola intestinalis STEUER on the meat content of the mussel Mytilus edulis L. Aquaculture 6:83-97

Diederich S (2005) Differential recruitment of introduced Pacific oysters and native mussels at the North Sea coast: coexistence possible? J Sea Res 53(4):269-281

Diederich S (2006) High survival and growth rates of introduced Pacific oysters may cause restrictions on habitat use by native mussels in the Wadden Sea. J Exp Mar Biol Ecol 328(2): 211-227

Diederich S, Nehls G, van Beusekom JEE, Reise K (2005) Introduced Pacific oysters (Crassostera gigas) in the Northern Wadden Sea: invasion accelerated by warm summers? Helgol Mar Res 59:97-106

Eno NC, Clark RA, Sanderson WG (1997) Non-native marine species in British waters: a review and directory. Joint Nature Conservation Committee, Peterborough

Folmer O, Black M, Hoeh W, Lutz R, Vrigenhoek R (1994) DNA primers for amplification of mitochondrial cytochrome $\mathrm{c}$ oxidase subunit I from diverse metazoan invertebrates. Mol Mar Biol Biotech 3:294-299

Gee JM, Davey JT (1986) Stages in the life history of Mytilicola intestinalis STEUER, a copepod parasite of Mytilus edulis (L.), and the effect of temperature on their rates of development. ICES J Mar Sci 42:254-264

Gotto V (2004) Commensal and parasitic copepods associated with marine invertebrates: keys and notes for the identification of British species. Second edition. Synopses of the British fauna (new series), 46. Field Studies Council, Shrewsbury, UK

Grizel H (1985) Mytilicola orientalis MORI, parasitism parasitose a Mytilicola orientalis. MORI. In: Sindermann DJ (ed) Fiches d'identification des maladies et parasites des poissons, crustaces et mollusques. Conseil international pour l'exploration de la mer, Copenhagen, pp 1-4

Higgins DG, Sharp PM (1988) CLUSTAL: a package for performing multiple sequence alignment on a microcomputer. Gene 73:237-244

His E (1977) Observations préliminaires sur la présence de Mytilicola orientalis MORI (1935) chez Crassostrea gigas THUNBERG dans le Bassin d'Arcachon. Bull Soc Géol Amis Mus Havre $64: 7-8$

His E, Tige G, Rabouin MA (1978) Mytilicola orinetalis Mori: son action sur les huitres du bassin d'Arcachon au sours de l'été et de l'automne. ICES CM 1978/K 13:1-12

Holmes JMC, Minchin D (1995) Two exotic copepods imported into Ireland with the Pacific Oyster Crassostrea gigas (Thunberg). Ir Nat J 25(1):17-20
Huys R, Llewellyn-Hughes J, Olson PD, Nagasawa K (2006) Small subunit rDNA and Bayesian inference reveal Pectenophilus ornatus (Copepoda incertae sedis) as highly transformed Mytilicolidae, and support assignment of Chondracanthidae and Xarifiidae to Lichomolgoidea (Cyclopoida). Biol J Linn Soc $87: 403-425$

Katkansky SC, Sparks AK, Chew KK (1967) Distribution and effects of the endoparasitic copepod, Mytilicola orientalis on the Pacific oyster, Crassostrea gigas, on the Pacific coast. Proc Natl Shellfish Ass 57:50-58

Korringa P (1968) On the ecology and distribution of the parasitic copepod Mytilicola intestinalis STEUER. Bijdr Dierkd 38:47-57

Krakau M, Thieltges DW, Reise K (2006) Native parasites adopt introduced bivalves of the North Sea. Biol Invasions 8:919-925

Lauckner G (1983) Diseases of Mollusca: Bivalvia. Dis Mar Anim 2:477-1038

Mann H (1979) The influence of Mytilicola intestinalis (Copepoda parasitica) on the development of the gonads of Mytilus edulis. Rapp PV Reun Cons Int Explor Mer 140:57-58

Meyer PF, Mann H (1950) Beiträge zur Epidemiologie und Physiologie des parasitischen Copepoden Mytilicola intestinalis. Arch Fischereiwiss 2(3/4):120-134

Minchin D, Gollasch S, Cohen AN, Hewitt CL, Olenin S (2009) Characterizing vectors of marine invasion. In: Rilov G, Crooks JA (eds) Biological invasions in marine ecosystems. Springer, Berlin, pp 109-116

Mori T (1935) Mytilicola orientalis, a new species of parasitic Copepoda. Zool Soc Jpn 47(564):687-693

Nehls G, Diederich S, Thieltges DW, Strasser M (2006) Wadden Sea mussel beds invaded by oysters and slipper limpets: competition or climate control? Helgol Mar Res 60:135-143

Odlaug TO (1946) The effect of the copepod, Mytilicola orientalis upon the Olympia oyster, Ostrea lurida. Trans Am Microsc Soc 65:311-317

Pillay TVR (2004) Aquaculture and the environment. Blackwell, Oxford, p 196

Reise K (1998) Pacific oysters invade mussel beds in the European Wadden Sea. Senckenb Marit 28:167-175

Reise K, Olenin S, Thieltges DW (2006) Are aliens threatening European aquatic coastal ecosystems? Helgol Mar Res 60:77-83

Rilov G, Crooks JA (eds) (2009) Biological invasions in marine ecosystems. Ecol Stud 204. Springer, Berlin, Heidelberg, p 641

Ruiz GM, Carlton JT, Grosholz ED, Hines AH (1997) Global invasions of marine and estuarine habitats by non-indigenous species: mechanisms, extent, and consequences. Am Zool 37:621-632

Steele S, Mulcahy MF (2001) Impact of the copepod Mytilicola orientalis on the Pacific oyster Crassostrea gigas in Ireland. Dis Aquat Organ 47:145-149

Steuer A (1902) Mytilicola intestinalis n.gen. n.sp. aus dem Darm von Mytilus galloprovincialis Lam. Zool Anz 25:635-637

Stock JH (1993) Copepoda (Crustacea) associated with commercial and non-commercial Bivalvia in the East Scheldt, The Netherlands. Bijdr Dierkd 63(1):61-64

Theisen BF (1966) Mytilicola intestinalis Steuer in Danish Waters 1964-1965. Medd Dabmark Fiskeri- og Havunders NS 4: 327-337

Theisen BF (1987) Mytilicola intestinalis STEUER and the condition of its host Mytilus edulis L. Ophelia 27(2):77-86

Thieltges DW, Krakau M, Andresen H, Fottner S, Reise K (2006) Macroparasite community in molluscs of a tidal basin in the Wadden Sea. Helgol Mar Res 60:307-316

Thieltges DW, Hussel B, Hermann J, Jensen KT, Krakau M, Taraschewski H, Reise K (2008) Parasites in the northern Wadden Sea: a conservative ecosystem component over 4 decades. Helgol Mar Res 62(1):37-47 
Torchin ME, Lafferty KD (2009) Escape from parasites. In: Rilov G, Crooks JA (eds) Biological invasions in marine ecosystems. Ecol Stud 204. Springer, Berlin, Heidelberg, pp 203-214

Torchin ME, Lafferty KD, Dobson AP, McKenzie VJ, Kuris AM (2003) Introduced species and their missing parasites. Nature 421:628-630

Troost K (2009) Pacific oysters in Durch estuaries. Ponsen and Looijen, Ede. Diss. Univ., Groningen, NL

White TJ, Bruns T, Lee S, Taylor JW (1990) Amplification and direct sequencing of fungal ribosomal RNA genes for phylogenetics. In: Innis MA, Gelfand DH, Sninsky JJ, White TJ (eds) PCR protocols: a guide to methods and applications. Academic Press, Inc., New York, pp 315-322

Williams CS (1969) The effects of Mytilicola intestinalis on the biochemical composition of mussels. J Mar Biol Assoc UK 49:161-173

Wolff WJ, Reise K (2002) Oyster imports as a vector for the introduction of alien species into northern and western Euopean coastal waters. In: Leppäkoski $\mathrm{E}$ et al (eds) Invasive aquatic species of Europe. Kluwer Academic Publ, Netherlands, pp 193-205 